\title{
LAW POLITIC OF ADMINISTRATIVE COURT JUDICATURE IN INDONEESIA
}

\author{
Wahyu Beny Mukti Setiyawan \\ Law Faculty of Islam Batik Surakarta University \\ muktibeny@gmail.com \\ Fitriya Dessi Wulandari \\ Law Faculty of Islam Batik Surakarta University \\ fitriyadessi@gmail.com
}

\begin{abstract}
Law politic present at the point of encounter between living realism and the demands of idealism. Political law concerns on an ideal or hope, then there is a legal vision that is set in advance, then the form and content of the law are built to realize that vision. The urgency existence of administrative justice in realizing the rule of law encourages the government to establish a legal system in the field of administrative justice through the establishment of Law Number 51986 about State Administrative Courts, which is the foundation for the establishment of a State Administrative Court in Indonesia. In the explanation of Law Number 5 of 1986 stated that the State Administrative Court was held in order to provide protection to the people seeking justice, which felt themselves to be harmed by a State Administrative Decision. Principly, a country is expected to give protection for the human rights of its citizens
\end{abstract}

Keywords: Indonesia, Law Politic, State administration court.

\section{A. INTRODUCTION}

Indonesia is a law based country (rechtsstaat), not based on power (machtsstaat). Thus, stated explicitly in Article 1 verse (3) of the 1945 Constitution of the Republic of Indonesia. Embryonically, the idea of law country was put forward by Plato, when he introduced the concept of nomoi. In the concept of nomoi, Plato argues that the administration of a good state is based on good legal regulation (Tahir Azhary, 1992: 66).

As law country, Indonesia accepts the law as an ideology to create order, security, justice and prosperity for its citizens. The consequence of it all is that the law binds every action taken by Indonesian citizens. Besides that, in Indonesia there is also a special attribute, namely Pancasila. This implies that the Pancasila as the Rule of Law is not merely a regulation that applies to Indonesian society. Otje Salman also commented in this regard that placing the system in certain idealism that is final, dynamic and always looking for ideal goals based on Pancasila ideology (R. Otje Salman Soemadiningrat, 2002: 139).

The 1945 Constitution of the Republic Indonesia as the basis of the Indonesian State Constitution has explicitly stated the form of Indonesian Government as written in Article 1 verse (3) of the 1945 Constitution of the Republic Indonesia that " Indonesia is a Law Country". In the concept of the law country (rechsstaat), it is idealized that what must be made a commander in the dynamics life of a country is law, not based on power (machsstaat). 
Related to the concept of a Law Country, F.J. Stahl formulated rechtsstaat elements, namely the protection of human rights, separation or division of country power to guarantee human rights, the Government based on regulations and the existence of Administrative Courts (S.F. Marbun, 2011: 9).

Basically the legal concept will never be separated from the goal for obtaining justice, because one of the objectives of the law is to realize justice for all people. Justice itself is something abstract which is difficult for humans to get a definite understanding the meaning of justice itself. When we talk about justice, in fact we must reflect that we do not live in this world individually so we are required not to ignore responsibility to others. The problem of justice is not enough to be achieved by human knowledge, because justice is an irrational ideal.

Every nation and country has a different law concept from one another. Although the concept adopted is different, the law has the same goal, namely the ideal goal of the law itself. The law has the vision and mission. The legal vision is determined first, because with this vision a design will be formed the form and content of the law itself which will be realized later. Law vision is the starting point of legal politics, because talking about legal politics is inseparable from ideals or expectations so there must be a vision first.

Law Politic is necessary, because the law is necessary. Law is needed to make things better. That is the idealism behind the legal presence in the human community from the very beginning. Therefore, legal politics is present, at the point of encounter between living realism and the demands of idealism. He corrects the situation that is "less ideal" and simultaneously presents "what should be". Because if "what exists" is already good, then indeed legal politics is no longer needed (Bernard L. Tanya, 2011: 13).

In making legislation, legal politics has a very important role. First, as a reason why it is necessary to establish a law. Second, to determine what is to be translated into legal sentences and become Article formulations. These two things are important because the existence of legislation and Article formulation is a bridge between legal politics in the implementation phase of legislation (Abdul Latif and Hasbi Ali, 2011: 19).

Administrative justice, as one of the elements in rechsstaat, is intended to provide legal protection to citizens for Government actions in the field of State Administration. As stated by Anna Erliyana quoting W.R. Wade \& C.F. Forsyth emphasized the main purpose of Administrative Law: the primary purpose of administrative law, therefore, is to keep the powers of government within their legal bounds, so as to protect the citizen against their abuse. Meanwhile, according to Mindainda Batalli, administrative procedures are mechanisms for interaction between public authorities and citizens (http://www.epracticejournal.eu. European Journal of ePractice). With the existence of Administrative Law, the Government's administrative actions towards the people are more directed. While Administrative Procedure Law as a mechanism of interaction between the government and the people, if there are problems between the two.

On the other hand, the Administrative Court will also provide the same legal protection to officials of the State Administration who act correctly and in accordance with the Law (S.F. Marbun, 2011: 10). Thus the presence of the Administrative Court can provide legal protection to both citizens and officials against Government Administrative actions.

The urgency of Administrative Courts existence in realizing the rule of law encourages the government to establish a legal system in the field of administrative justice, namely through the establishment of Law Number 5 of 1986 about State 
Administrative Courts, which is the foundation for the establishment of a State Administrative Court in Indonesia. In the explanation of Law Number 5 of 1986 it was stated that the State Administrative Court was held in order to provide protection to the people seeking justice, which felt themselves to be harmed by a State Administrative Decision.

There is an empirical fact that the decision of the State Administrative Court is still limited to "macam kertas", this is shown by Supandi's dissertation which found that most officials in North Sumatra, around $71.41 \%$, did not comply with the Medan Administrative Court Decision. In 2004, DR. Supandi examined 180 decisions of the Medan PTUN (out of 2000 decisions since the period 1991-2003) which had permanent legal force and execution values. Of these, only around $20.59 \%$ of the decisions were carried out by Defendant officials

(http://Kompas.com/kompascetak/061/13/politikhukum/2359537.htm). That in reality the existence of the TUN Judiciary has not been able to provide guarantees of protection for people seeking justice. So that improvements are needed in the TUN Judicial system in Indonesia.

Reformation of the TUN Judicial system in Indonesia was marked by changes to Law Number 5 of 1986 concerning Administrative Court. The first change was made through the stipulation of Law Number 92004 concerning Amendments to Law Number 5 of 1986 concerning Administrative Court. Furthermore, through the stipulation of Law Number 512009 concerning the Second Amendment to Law Number 51986 concerning Administrative Court. Changes to Law Number 51986 concerning PTUN are in principle a result of amendments to the 1945 Constitution. The amendment is intended to strengthen the principle of an independent judicial power free from the influence of other powers in organizing justice to uphold law and justice. In connection with the background that has been described as above, the author intends to examine how the Law Politic Administrative Courts Law Politic in Indonesia.

\section{B. RESEARCH METHODOLOGY}

\section{Type of Research}

This type of research is normative law or doctrinal research. Hutchinson, as quoted by Peter Mahmud Marzuki, defines doctrinal law research as follows, 'Doctrinal Reseach : Reseach wich provides a systematic exposition of rules governing a particular legal category, analyses the relationship between rules, explain areas of difficulty and perhaps, predict future development) "(Peter Mahmud Marzuki, 2010: 32).

\section{Types and Sources of Legal Materials}

In legal research there is no data, what is in legal research is legal material. Legal materials consist of primary legal materials, secondary legal materials and tertiary legal materials. Primary legal material, namely legal material consisting of legislation based on its hierarchy. Secondary legal material is a legal material consisting of textbooks written by influential jurists (de herseende leer), legal journals, opinions of scholars, legal cases, jurisprudence, and results the latest symposium relating to the topic of research. Tertiary legal materials are legal materials that provide guidance or explanation of primary legal materials and secondary legal materials, such as legal dictionaries, encyclopedia, and others (Johnny Ibrahim, 2006: 295-296). 


\section{Legal Material Collection Techniques}

The legal material collection technique in this study is to use the technique of library research (collecting by library). Collection of primary legal materials, secondary legal materials and tertiary legal materials are inventoried and classified by adjusting the issues discussed. Legal materials relating to the issues discussed are presented, systematized, then analyzed to interpret applicable laws (Johnny Ibrahim, 2006: 296).

\section{Analysis Techniques of Legal Material}

The legal material analysis technique used in this research is deductive logic. In this case, the source of research obtained in this study is by carrying out an inventory while at the same time studying the library research studies, legislation and documents that can help interpret the related norms, then the research sources are processed and analyzed to answer the problems studied. The final stage is to draw conclusions from the research sources that are processed. According to Philipus M. Hadjon as quoted by Peter Mahmud Marzuki, the method of deduction as syllogism taught by Aristotle uses the method of deduction based on the submission of a major premise (general statement). Then a minor premise is proposed. From the two premises, a conclusion or conclusion is drawn (Peter Mahmud Marzuki, 2010: 47). In syllogistic logic for legal reasoning which is a major premise is the rule of law while the minor premise is a legal fact. Meanwhile, according to Johnny Ibrahim, quoting the opinion of Bernand Arief Shiharta, deductive logic is a technique to draw conclusions from general things to specific individuals (Johnny Ibrahim, 2006: 249).

\section{DISCUSSION}

The existence of the State Administrative Court in Indonesia began with Law Number 51986 concerning State Administrative Courts (hereinafter referred to as the TUN Judiciary). In the dynamics of the state administration which continued to experience development, especially after the amendment to the 1945 Constitution of the Republic of Indonesia, brought important changes to the implementation of judicial power.

In line with Lon Fuller's opinion in Principles of Legality that "A system must not contain rules that contradict each other", then the stipulation of Law Number 4 of 2004 concerning Judicial Power (Law Number 48 of 2009) has consequences on Law Number 5 of 1986 concerning State Administrative Courts. Considering the Judicial Power as stipulated in the 1945 Constitution of the Republic of Indonesia includes General Courts, Religious Courts, Military Courts and Administrative Courts under one roof, namely the Supreme Court. So that synchronization of the justice system including the TUN Judiciary is needed. Therefore, Law Number 9 of 2004 concerning the Amendment to Law Number 5 of 1986 concerning TUN Judiciary was enacted.

The principle change contained in Law No. 9 of 2004, was the abolition of dualism in the judicial power, becoming a roof under the authority of the Supreme Court. These changes are in the framework of applying neutral justice principles in the system of State Administrative Courts in Indonesia. Besides the changes in Law Number 9 of 2004 concerning Amendments to Law Number 5 of 1986 concerning TUN Judiciary as stated in the Explanation of the Law, among others are the requirements to become a Judge in a court in the TUN Judiciary, the appointment deadline and dismissal of Judges, procedures for appointment and dismissal of Judges, elimination of provisions of procedural law governing the entry of 
third parties in a dispute and the existence of sanctions against officials who do not carry out court decisions that have permanent legal force.

In 2009 the second change was made to Law Number 8 of 1986, namely through the enactment of Law Number 51 of 2009 concerning the Second Amendment to Law Number 5 of 1986 concerning TUN Justice. The Second Amendment to Law No. 5 of 1986 concerning the TUN Judiciary is basically to realize the implementation of an independent Judicial Power and a clean and authoritative judiciary, which is carried out through an integrated justice system (Law Number 51 of 2009 ). Some important changes regarding the TUN justice as stipulated in Law Number 9 of 2004 and Law Number 51 of 2009 concerning the Second Amendment to Law Number 5 Year 1986 concerning the TUN Judiciary will be discussed further in the following description:

1. Removing dualism in judicial power, becoming a roof under the authority of the Supreme Court

One of the principle changes to Law Number 9 of 2004 is regarding the administration of judicial power. The change was intended as an effort to strengthen the principle of an independent judicial power and be free from the influence of other powers to conduct justice to uphold law and justice. As one of the elements of rechtsstaat as formulated by F.J. Stahl is a separation or division of power to guarantee human rights. Separation or division of power includes the separation of executive, legislative and judicial powers. So to maintain the independence and freedom of the judiciary in carrying out its functions and roles, separation from executive power is a matter of principle.

The development of the organization, administration and finance of the court by the Ministry of Justice is deemed no longer in line with the spirit of the constitution. Technical and organizational development and finance should be carried out under one roof, namely by the Supreme Court. Then through Act No. 9 of 2004 the elimination of dualism is carried out in the judicial power, into one roof, which is under the sole roof of the Supreme Court.

As stated in Article 7 Number 9 2004, "The technical guidance of the judiciary, organization, administration and finance of the Court is carried out by the Supreme Court". The provisions in Article 7 Number 9 of 2004 put an end to the dualism of the holding of judicial power, which was originally carried out by the Minister of Justice and the Supreme Court. This provision is certainly in line with the principle of neutral justice. The task of supervising and appointing and dismissing judges which were originally the authority of the Minister of Justice, turned into the duties of the Supreme Court. Thus it is expected to be able to realize an independent and free TUN Judiciary as mandated by the 1945 Constitution of the Republic of Indonesia.

\section{Appoitment and dissmisaal of judges}

\section{a. Tightening the conditions to become a Judge in the TUN Judicial environment}

The requirements for being able to become a TUN Judge are regulated in Article 14 verse (1). The requirement to become a Judge in the TUN Judiciary environment is increasingly tightened. In Article 14 verse (1) of Law Number 51 of 2009 it is stated that to be appointed as a Judge of the State Administrative Court must be a Bachelor of Law and pass the Judge's education. This is different from the provisions of the previous Law, which does not absolutely require the educational competence of prospective Judges. It is expected that 
with the education competency Judges who come from the Faculty of Law, will later be able to have capability in the field of Law, considering the duties of the Judges of TUN are relatively heavier. In the TUN Judiciary the principle of the active Judge is known, where the Judge is entrusted with the task of finding the material truth about the dispute that he examined. So that the mastery of Judges in the field of Law is an important matter

Besides educational competency requirements, another important thing required by Law Number 51 of 2009 is that it has never been sentenced to prison for committing a crime based on a court decision that has obtained permanent legal force. In addition to competence in the field of Law, a prospective Judge must also have a good trace partner. With the increasingly stringent requirements in the appointment of Judges in the TUN Judiciary environment, it is expected to produce competent Judges so that they can provide justice for the people in dispute in the Administrative Court

\section{b. Judge Dismissal}

In addition to the renewal of regulations regarding the appointment of Judges, in Law Number 92004 and Law Number 512009 also made improvements regarding dismissal of Judges in the TUN Judicial environment. Some changes regarding dismissal of Judges in the TUN environment include:

1) The change in retirement age for Judges;

2) The change in reasons for termination not respectfully Judges are increasingly clarified;

3) Dismissal of the Chairperson or Deputy Chairperson of the Court from his position because at his own request in writing is not automatically terminated as a Judge (Article 21 of Law Number 51 2009). This is different from the provisions in Law Number 51986 that a Judge dismissed from his position does not automatically terminated as a civil servant;

4) Chairperson, Deputy Chairperson and Court Judge whose position is by the Chair of the Supreme Court (Article 22 paragraph (1)). Whereas in Law Number 5 1986, a temporary dismissal is carried out by the President as the Head of State at the suggestion of the Minister of Justice based on the approval of the Chief Justice of the Supreme Court. This of course can affect the independence and freedom of the Judge.

\section{Supervision of Judges in the TUN Judicial environment;}

There have been changes in the supervision of the Judge. Initially supervision of Judges in the TUN Judiciary was carried out by the Minister of Justice as stipulated in Article 13 verse (1), "Guidance and general supervision of Judges as civil servants was carried out by the Minister of Justice". Supervision of Judges by the Minister of Justice, which is part of Executive Power, is of course contrary to the principle of neutral justice because it can threaten the freedom of Judges as organizers of judicial power. Based on this, then in Law Number 9 of 2004 there was a change in the guidance of Judges in the TUN Judicial environment.

In Article 13 verse (1) of Law Number 9 2004, it is stated that "General guidance and supervision of Judges is carried out by the Supreme Court". In the article, the Judge is not only supervised as a civil servant, but his full capacity as a Judge. The supervision was carried out by the Chair of the Supreme Court, as the 
highest judicial power holder. This of course has been in line with the mandate of the constitution, in the framework of forming a free and independent judiciary.

The provisions regarding supervision of Judges in the TUN Judicial Environment have changed again in Law Number 51 2009. In Law Number 51 of 2009, there is an additional new article, Article $13 \mathrm{~A}$, which states that internal supervision of judges' conduct is carried out Supreme Court. In addition to Supervision as referred to in paragraph (1), to maintain and uphold the honor, nobility, dignity and behavior of judges, external supervision of the conduct of judges is carried out by the Judicial Commission.

The provisions in Article 13 A of Law Number 512009 improve the regulation regarding supervision of Judges. Supervision is divided into internal supervision and external supervision. Internal supervision is carried out comprehensively by the Supreme Court (no longer mentioning the position of "Chief Justice of the Supreme Court"). Whereas external supervision is carried out by the Judicial Commission. This is in accordance with the duties of the Judicial Commission as stipulated in Article 20 of Law Number 22 Year 2004 concerning the Judial Commission, that "In exercising the authority as referred to in Article 13 verse B the Judicial Commission has the duty" to supervise the conduct of Judges in order to uphold honor nobility and guarding the behavior of Judges ".

\section{Reason of Claim Submission}

In Article 53 verse (1) of Law Number 9 of 2004, it is stated that, "A person or body of civil law who feels that his interests are harmed by a State Administrative Decision can submit a written claim to the competent Court which demands that the State Administrative Decree disputed was declared null and void, with or without a claim for compensation and / or rehabilitation. While the basis for filing a lawsuit is regulated in Article 53 verse (2), where there are quite basic differences in Law Number 5 Year 1986 and Law Number 9 of 2004.

According to the provisions of Law Number 5 of 1986, the basis or reason for filing a lawsuit against a decision issued by a TUN body or official, because the TUN decision is contrary to the applicable Laws and Regulations, either procedural or formal and material or substantial, or because it was issued by the Agency or TUN Officer who is not authorized, issued on the basis of abuse of authority and issued on the basis of arbitrary acts.

In Law Number 9 2004, the basis or reason for the claim against the TUN decision is that the KTUN contradicts the applicable Laws and Regulations, as stipulated in Law Number 5 Year 1986 and KTUN contradict general principles of good governance. The principle is not a norm that is easily measured in its implementation. Clarity of the authority to examine the types of disputes will facilitate the Judge examining and adjudicating the TUN dispute submitted by the Plaintiff (the people). And will provide convenience for the people in measuring the actions of administrative officials who are indicated to harm the interests of the people. This is in accordance to one of the points in the Principles of legality that, "Regulations must be arranged in an understandable formula". So that it will provide clarity and narrow the multi-interpretation in its application.

\section{Bailiff}

There is something new in Law Number 9 of 2004, which is a regulation concerning bailiffs in the TUN Court, as stated in Article 39 verse A that, "In each 
State Administrative Court a bailiff is stipulated". The court bailiff was appointed by the Supreme Court with the following conditions as Indonesian citizens, fearing the Almighty God, loyal to Pancasila and the 1945 Constitution of the Republic of Indonesia, having a high school certificate (amendment to Law Number 51 of 2009 ), having the shortest experience of 3 (three) years as a substitute bailiff and capable spiritually and physically to carry out duties and obligations.

Provisions regarding the bailiff are regulated in Article 39 A - $39 \mathrm{E}$ of Law Number 9 2004. However, in the Act it has not been clearly stated the duties and authority of the surrogate and bailiff, as well as in Law Number 512009.

\section{Regulations concerning special courts and ad hoc judges;}

In Law Number 9 of 2004, there are new provisions regarding special courts. In Article 9 A of Law Number 9 of 2004 it is stated that, "In the State Administrative Courts, specialization can be carried out regulated by Law. The specialization referred to in Article $9 \mathrm{~A}$, is in the form of differentiation or specialization in the State Administrative Court, for example the Tax Court. Provisions regarding the Special Court were revised again in Law Number 51 2009, that in special courts ad hoc judges can be appointed to examine, hear and decide cases that require expertise and experience in certain fields and within a certain period of time.

\section{Transparency implementation of decisions;}

In the TUN Judiciary there is one principle adopted from Administrative Law, namely the principle of Prae Sumptio Ius Causa, namely Keputusan Tata Uasaha Negara (KTUN), a State Administrative Decree, which is considered valid until there is a cancellation from the Court. Thus, the implementation of the Administrative Court Decision is an important key in a TUN dispute for justice seekers. Provisions regarding the implementation of decisions are stipulated in Article 116 of Law Number 5 Year 1986 (and their amendments).

The legal conditions in Indonesia that often do not comply with the decisions of the State Administrative Court are different from the conditions of other countries which tend to be well established in the practice of their rule of law. In a comparative study between Administrative Courts in France, the Netherlands, Belgium and Luxembourg (Conseil D'Etat), Germany (Bundesverwaltungsgericht), Greece (Symvoulion Epikratias), Italy (Consiglio di Stato), Spain (Tribunal Supremo), Switzerland (Federal Tribunal) and the European Union Court of Justice, Frank Esparraga got one conclusion that the implementation of the Administrative Court Decision in these countries did not experience significant obstacles, because in general the public authorities carried out the Court Decision "... however, it can be said that in the countries examined, public authorities generally apply the decisions of courts"(http://www.ptunpalu.go.id/index.php?option=com_content\&view=category \&id=1\&Itemid=341).

The adherence of the PTUN Judge's decision by the defendant, in this case the State officials, gave rise to a new execution institution in Law Number 9 of 2004 and Law Number 51 2009, namely forced money and administrative sanctions. In addition, sanctions in the form of announcements in printed media were also applied to officials who were reluctant to comply with the verdict. 
The process of implementing TUN Judicial decisions, through Law Number 9 of 2004 and Law Number 51 2009, shows the use of fixed execution systems, namely executions whose implementation can be enforced by the Court through the means of enforcement stipulated in the Laws and Regulations (http://ar1fmaulana.blog.uns.ac.id/2011/11/09/perbandinganmekanismepelimpleme nt-putusan-peradilan-administrasi-antara-indonesia-dengan-dithailand/). This is different from the execution of the TUN Judicial verdict carried out in Law No. 5 of 1986 which is more influenced by the principle of self respect / self obedience and the floating execution system, namely the authority to carry out Court Decisions that have permanent legal force, fully handed over to the agency or official authorities without the authority of the TUN Courts to impose sanctions.

In the implementation level it turns out that the two institutions have many problems, namely the absence of legal products governing the procedures and mechanisms for paying forced or administrative sanctions, on whom the forced money is charged, whether on the personal finances of officials or the state administration officials and sanctions what administration will be handed down to the defendant who is reluctant to implement the decision (http://m.hukumonline.com/berita/baca/hol211227).

Related to the sanctions for payment of forced money and administrative sanctions, we can learn from the implementation of the Decision of the Thai Administrative Court. If the Court's decision concerns the obligation to pay a sum of money or delivery of goods, the Court can execute the assets concerned. This is in accordance with the Theory of Fautes Personalles, namely the theory which states that losses to third parties are charged to officials who because their actions causeharm(http://www.ptun.palembang.go.id/upload_data/penerapan\%20usaha\%2 Ohukum\%20paksa.pdf). Whereas if the Court Decision involves an order to do or not commit an act, then the Court can carry out the execution using the Civil Procedure Code mutatis mutandis.

The clarity of the regulation regarding the implementation of the Court's Decision in the Administrative Court of Thailand will certainly provide legal guarantees or protection for the justice seekers, because practically the absence of regulations regarding the procedures for enforcing these efforts has not yet been implemented, resulting in a TUN Court Decision that has permanent legal force and the TUN Court's decision will still be a "Macan Ompong".

\section{Transparency of case costs;}

In justice system, known a principles, namely the principle of fast, simple and low cost justice. In order to cover this principle, a new arrangement was made in Law Number 51 of 2009 concerning the transparency of case costs, namely Article $144 \mathrm{~A}-144 \mathrm{~B}$. In Article 144 A paragraph (1) it is stated that, "In carrying out the duties of the Judiciary, Administrative Courts The state can withdraw court fees ". Case costs include the administrative costs and costs of completing the case. In the event that the plaintiff is unable to pay the court fees, then the State that bears it, as stipulated in Article $144 \mathrm{C}$ paragraph (2), "The State shall bear the costs of cases for incompetent justice seekers".

In order for transparency, the withdrawal of case fees must be accompanied by a valid proof of payment. Officials in the TUN Judiciary are prohibited from withdrawing fees other than the courtesy fee and the cost of the settlement 
process. If there are officials who are proven to violate these provisions, sanctions can be imposed in the form of a non-respectful dismissal. Transparency in the implementation of public services is an important matter. Enforcement of transparency in withdrawing court fees is done so that the administration of the Judiciary can be cleared of KKN.

\section{Legal assistance.}

In order to provide protection for people seeking justice in litigation at the Administrative Court, each person who is litigated is given the right to obtain legal assistance (Article 144 C verse (1) of Law Number 51 2009). Law No. 51 of 2009 mandates the establishment of Legal Aid Posts, Pos Bantuan Hukum (POSBAKUM) in each State Administrative Court for incapable justice seekers. Legal assistance is provided free of charge from the first court level to the execution of the verdict.

\section{CLOSING}

\section{CONCLUSION}

Indonesia is a law country, so that the existence of a State Administrative Court is a necessity in order to protect the rights of citizens from the actions of the Government. The history of the existence of the State Administrative Court in Indonesia began with the enactment of Law Number 1986 concerning the State Administrative Court. Along with the development of the constitutional system in Indonesia, it is reasonable to make changes to Law Number 5 of 1986 . This is done in the context of synchronizing the legal system regarding judicial power in Indonesia.

The main changes in Law Number 9 of 2004 concerning Amendments to Law Number 5 of 1986 concerning Judiciary and Law Number 51 of 2009 concerning the Second Amendment to Law Number 5 of 1986 concerning TUN Courts are as follows: dualism in the judicial power, being one roof under the authority of the Supreme Court, tightened requirements to be a Judge, and clearer arrangements regarding dismissal of Judges, supervision of Judges in the TUN Judicial environment conducted internally by the Supreme Court and external supervision by the Judicial Commission, reason or the basis for filing a claim, namely the TUN Decree that is contrary to the Laws and the general principles of good governance, the existence of a bailiff, the existence of a special Court and ad hoc Judges, transparency of decisions and the existence of forced efforts (payment of forced money and administrative sanctions) if the TUN Decision has power Law is still not implemented, transparency in case costs and the existence of Legal Aid for justice seekers.

\section{RECOMMENDATION OR SUGGESTION}

The existence of Law No. 92004 and Law No. 512009 further improved the existence of Law No. 5 1986. However, there are still some ambiguities in the specific arrangements regarding the existence of bailiffs, the basis of claims and the implementation of forced efforts (forced money and administrative sanctions). Related to this, the author gives the following suggestions:

It should be arranged in more detail about the duties, obligations and authority of the bailiff in the TUN Court. This is also related to the role of bailiffs in implementing administrative efforts, namely in the form of payment of forced money. 
a. Related with the basis or reason for a lawsuit in the TUN Court, because of the TUN Decision that is contrary to the Laws and the general principles of good governance. The basis or reason for the TUN lawsuit should be more detailed and formulated in a clearer formula, so as not to cause various interpretations.

b. There is still a regulatory vacuum regarding the implementation of forced efforts, both for forced payments and administrative sanctions. Regarding the payment of forced money, according to the authors the execution can be carried out on the assets of the officials concerned.

\section{BIBLIOGRAPHY}

Abdul Latif dan Hasbi Ali, Politik Hukum, Penerbit Sinar Grafika, Jakarta, 2011.

Arif Maulana, "Perbandingan Mekanisme Pelaksanaan Putusan Peradilan Administrasi antara Indonesia dengan Thailand", http://ar1fmaulana.blog.uns.ac.id/2011/11/09/perbandingan-mekanismepelaksanaan-putusan-peradilan-administrasi-antara-indonesia-dengan-di-thailand/. diakses tanggal 03 Maret 2019 Pukul 19.50 WIB.

Bernard L. Tanya, Politik Hukum Agenda Kepentingan Bersama, Penerbit Genta Publishing, Yogyakarta, 2011.

Enrico Simanjuntak, "Tinjauan Singkat Tentang Perkembangan Hukum Administrasi di Negara Anggota Uni Eropa", http://www.ptunpalu.go.id/index.php?option=com content\&view=category\&id=1\&Itemid=341, diakses 03 Maret 2019 Pukul 19.45 WIB.

Http://m.hukumonline.com/berita/baca/hol211227, diakses tanggal 03 Maret 2019 Pukul 19.48 WIB.

Johnny Ibrahim, Teori dan Metodologi Penelitian Hukum Normatif cetakan kedua, Penerbit Bayumedia Publising, Malang, 2006.

Mirlinda Batalli, "Simplification Of Public Administration Through Use Of Ict And Other Tools", http://www.epracticejournal.eu. European Journal of ePractice diakses tanggal 03 Maret 2019 Pukul 19.38 WIB.

Peter Mahmud Marzuki, Penelitian Hukum, Penerbit Kencana Prenada Media Group, Jakarta, 2010.

R. Otje Salman Soemadiningrat, Rekonseptualisasi Hukum Adat Kontemporer, Penerbit Alumni, Bandung, 2002.

S.F Marbun, Peradilan Administrasi Negara dan Upaya Administrasi di Indonesia, Penerbit FH UII Press, Yogyakarta, 2011.

Susana Rita, "Belum Bertaring Karena Tak Punya Daya Paksa", http://Kompas.com/kompas-cetak/061/13/politikhukum/2359537.htm, diakses tanggal 03 Maret 2019 Pukul 19.34 WIB.

Tahir Azhary, Negara Hukum, Penerbit Bulan Bintang, Jakarta, 1992.

Ujang Abdullah, "Penerapan Upaya Hukum Paksa Berupa Pembayaran Uang Paksa Di Pengadilan Tata Usaha Negara", http://www.ptun.palembang.go.id/upload data/PENERAPAN\%20UPAYA\%20HUKU M\%20PAKSA.pdf, diakses tanggal 03 Maret 2019 Pukul 19.30 WIB. 
Undang-Undang Nomor 48 Tahun 2009 sebagai bentuk penyempurnaan Undang-Undang Nomor 4 Tahun 2004 tentang Kekuasaan Kehakiman.

Undang-Undang Nomor 51 Tahun 2009 tentang Perubahan Kedua Atas Undang-Undang Nomor 5 Tahun 1986 tentang Peradilan Tata Usaha Negara. 